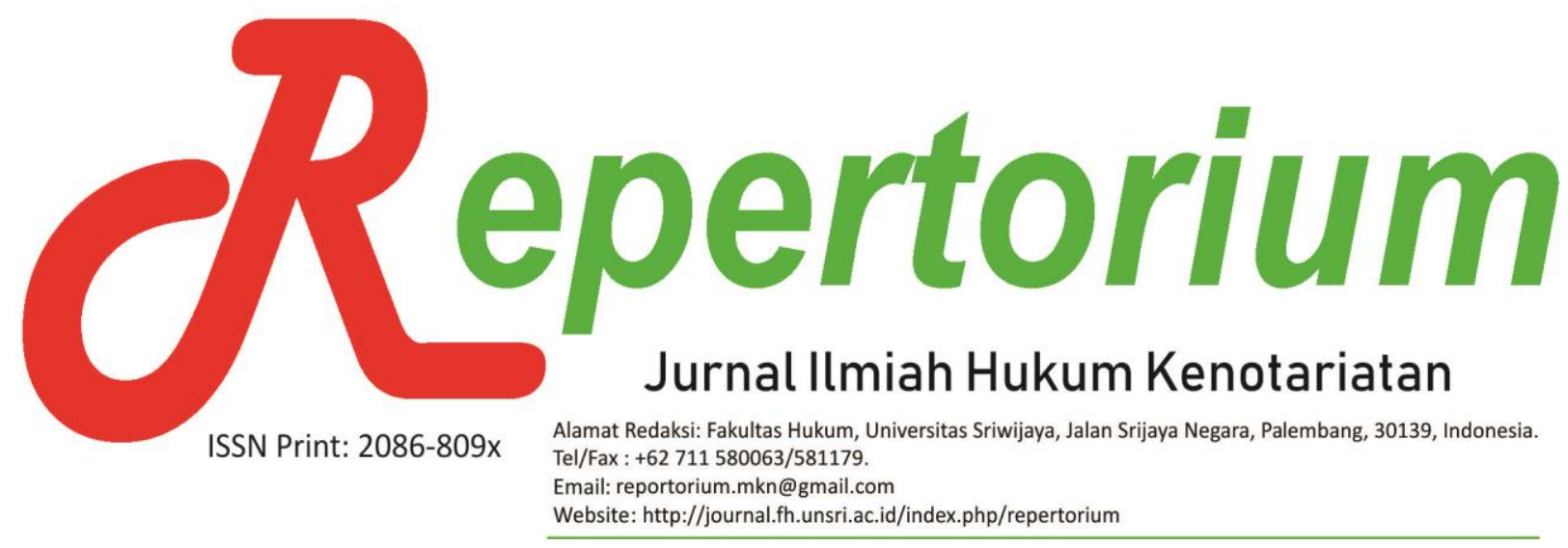

\title{
PERALIHAN KREDIT PEMILIKAN RUMAH MELALUI PERJANJIAN DI BAWAH TANGAN ANTARA DEBITUR AWAL DENGAN DEBITUR PENGGANTI
}

\section{Winda Agustini*}

\begin{abstract}
Abstrak: Salah satu fungsi Bank adalah menyalurkan dana dalam bentuk kredit kepada masyarakat, pemberian kredit yang disalurkan oleh Bank salah satunya adalah Kredit Pemilikan Rumah, sebagaimana yang dijelaskan dalam Penjelasan Pasal 1 UU Perbankan, Bank dalam menawarkan jasa kreditnya menyediakan sistem Peralihan Kredit atau take over. Namun seiring perkembangannya take over kadang disalahgunakan oleh nasabah yaitu nasabah melakukan tak over melalui perjanjian dibawah tangan tanpa diketahui oleh pihak bank, salah satunya yang terjadi pada PT. Bank Tabungan Negara (BTN) Persero. Penulis menemukan beberapa cara agar proses peralihan kredit tidak bertentangan dengan hukum, beberapa cara tersebut sebagai berikut: 1). Melalui Proses Resmi Bank, dan 2). Melalui Proses Resmi Notaris.
\end{abstract}

Kata kunci: Bank; Debitur; Kredit; Kreditur; Kredit Pemilikan Rumah.

* Magister Kenotariatan Fakultas Hukum Universitas Sriwijaya

\section{LATAR BELAKANG}

Ikatan hukum antara Bank sebagai kreditur/pemberi kredit dengan debitur sebagai penerima pinjaman adalah persetujuan atau kesepakatan pinjammeminjam yang dikenal sebagai perjanjian kredit. Pemberian kredit oleh suatu bank didasarkan atas dasar keyakinan. ${ }^{1}$ Sebagaimana yang diterangkan dalam Pasal 8 UU Perbankan, mengatur bahwa "Bank dalam menyalurkan kredit wajib

\footnotetext{
${ }^{1}$ Thomas Suyatno, 2007, Dasar-Dasar Perkreditan, Jakarta: PT. Gramedia Pustaka Utama, hlm. 14.
}

mempunyai keyakinan terhadap debitor untuk melunasi hutangnya". Pada azasnya dalam kegiatan menyalurkan kredit bank tidak diwajibkan untuk menyertakan agunan sebagai syarat yang harus ada, akan tetapi cukup dengan keyakinan dari bank terhadap debitor, untuk melunasi semua hutang-hutangnya. ${ }^{2}$

Pemberian kredit untuk pelunasan kredit lain ini identik dengan Subrogasi, sebagaimana yang dielaskan dalam Pasal 1400 KUHPerdata, yang menyatakan bahwa "Subrogasi adalah perpindahan hak

2 Rakhmad Susatyo, "Aspek Hukum Kredit Bermasalah Di PT. Bank International Indonesia Cabang Surabaya", Jurnal Hukum Vol. 7, No. 13, hlm. 14 . 
dan konstitutif bagi hukum. Bersifat normatif karena berfungsi sebagai prasyarat utama yang mendasari tiap hukum positif yang bermartabat, serta menjadi landasan moral hukum dan sebagai tolak ukur sistem hukum positif.

Sedangkan bersifat konstitutif karena keadilan harus menjadi unsur mutlak bagi hukum sebagai hukum, tanpa keadilan sebuah aturan tidak pantas menjadi hukum. ${ }^{5}$ Keadilan itu sendiri pada dasarnya merupakan suatu nilai tertinggi diantara nilai yang ada dalam hubungan antara manusia dalam hidup bermasyarakat, karena keadilan itu merupakan suatu integritasi dari berbagai nilai kebijaksanaan yang telah, sedang dan selalu diusahakan untuk dicapai dalam setiap waktu dan segala bidang serta masalah yang dihadapi dalam masa yang kian meningkat selaras dengan berkembangnya rasa keadilan dunia dan peradaban bangsa.

\section{Teori Perlindungan Hukum}

Perlindungan hukum merupakan gambaran dari bekerjanya fungsi hukum untuk mewujudkan tujuan-tujuan hukum, yakni keadilan, kemanfaatan dan kepastian hukum. Perlindungan hukum adalah suatu perlindungan yang diberikan kepada subyek hukum sesuai dengan aturan hukum, baik itu yang bersifat preventif maupun dalam bentuk yang bersifat represif, baik yang secara tertulis maupun tidak tertulis dalam rangka menegakkan peraturan hukum.

\section{a. Teori Fungsi Kontrak}

Fungsi kontrak dapat dibedakan menjadi dua macam, yaitu fungsi Yuridis dan fungsi Ekonomis. Fungsi yuridis kontrak adalah fungsi dapat memberikan kepastian hukum

\footnotetext{
${ }^{5}$ Ibid.
}

bagi para pihak. Sedangkan fungsi ekonomis adalah menggerakkan (hak milik) sumber daya dari nilai penggunaan yang lebih rendah menjadi nilai yang lebih tinggi.

3.

4. Teori Perjanjian Kredit

Perjanjian kredit adalah perjanjian yang diikuti dengan perjanjian jaminan. Perjanjian kredit berlaku sejak ditandatangani kedua pihak, kreditur dan debitur. Perjanjian kredit yang dibuat oleh pihak bank disiapkan dalam bentuk standar (standard form). Dalam pemberian kredit, bank tetap meminta agunan/jaminan dari pemohon kredit. Jaminan kredit adalah segala sesuatu yang mempunyai nilai untuk diuangkan yang diikat dengan janji sebagai jaminan untuk pembayaran dari hutang debitur berdasarkan perjanjian kredit yang dibuat kreditur dan debitur. ${ }^{6}$

\section{Metode}

Sifat Penelitian

Jenis penelitian ini adalah penelitian normatif, yaitu bentuk penelitian hukum yang dilakukan dengan cara meneliti bahan hukum pustaka data sekunder. ${ }^{7}$

\section{Pendekatan Penelitian}

Pendekatan yang digunakan dalam penulisan hukum ini adalah Pendekatan Perundang-undangan (statute approach) dan Pendekatan Kasus (case approach).

\footnotetext{
${ }^{6}$ Zainal Asikin, 1995, Pokok-Pokok Hukum Perbankan di Indonesia, Jakarta: PT. Raja Grafindo Persada, hlm. 17

${ }^{7}$ Soejono Soekanto, 2010, Penelitian Hukum Normatif Suatu Tinjauan Singkat, Jakarta : PT. Raja Grafindo Persada, hlm. 14.
} 


\section{Bahan Penelitian}

Bahan penelitian hukum dalam penelitian tesis ini ada 2 (dua) macam, yaitu :

Bahan Hukum Primer: Kitab UndangUndang Hukum Perdata (BW) dan UU Nomor 7 Tahun 1992 tentang Perbankan beserta perubahannya, yaitu UU Nomor 10 Tahun 1998.

Bahan hukum sekunder yang memberikan penjelasan terhadap bahan-bahan hukum primer, seperti : buku ilmiah hukum, jurnal hukum, laporan hukum, dan media cetak atau elektronik. ${ }^{8}$

\section{ANALISIS DAN DIKSUSI}

Proses terjadinya dan akibat hukum yang timbul dalam peralihan kredit pemilikan rumah melalui perjanjian di bawah tangan antara debitur awal dengan pihak ketiga (debitur pengganti), tanpa persetujuan kreditur (PT. Bank Tabungan Negara (BTN) Cabang Palembang).

Kredit dalam kegiatan perbankan merupakan kegiatan usaha yang paling utama, karena pendapatan terbesar dari usaha bank berasal dari pendapatan usaha kredit yaitu berupa bunga dan provisi. Usaha perkreditan merupakan suatu bidang usaha dari perbankan yang sangat luas cakupannya serta membutuhkan penanganan yang profesional dengan integritas moral yang tinggi.

Etymologically, the credit comes from the word "credere", which means trust. In other words, Customers who obtain credit from banks are clients who have the trust from the bank. Credit can interpreted as a loan where the repayment is done in installments allowed by the bank or other entity. Based the legislation

${ }^{8}$ Abdulkadir Muhamad, 2004, Hukum dan Penelitian Hukum, Bandung : PT. Citra Aditya Bakti, hlm. 82. definition of credit is the provision of money/bills can be equated with that based on the agreement between bank lending with another party that requires the borrower to repay the debt after a certain period of time with interest. ${ }^{9}$

Proses alih debitur dalam kenyataannya di lapangan tidak selalu dilakukan dengan sepengetahuan atau izin pihak bank selaku kreditur. Penjualan rumah yang telah mendapatkan KPR-BTN di bawah tangan, merupakan suatu realitas yang terjadi dalam masyarakat.

Terjadinya alih debitur yang dilakukan di bawah tangan oleh debitur kepada pihak ketiga dapat terjadi karena: ${ }^{10}$

1) Debitur lama tidak lagi mampu melanjutkan angsuran KPR-BTN;

2) Debitur lama mengalami kesulitan ekonomi;

3) Debitur lama pindah domisili;

4) Debitur tidak beritikad baik untuk memenuhi kewajibannya;

5) Ketidakpahaman para pihak akan hukum khususnya tentang proses alih debitur.

Untuk mendukung penelitian, penulis akan memberikan beberapa contoh beberapa perkara yang berkaitan dengan proses pengalihan debitur yang dilakukan dibawah tangan tanpa sepengetahuan pihak bank oleh penerima fasilitas kredit KPRBTN pada putusan Pengadilan yang telah memiliki kekuatan hukum yang tetap, diantaranya sebagai berikut:

${ }^{9}$ Erma Deviana Putriyanti, "Legal Status of Credit Bank Guarantee in Indonesia's Legal Guarantee", Jurnal Hukum Sriwijaya Law Review, Volume 1, Issue 2, July 2017, hlm. 3 .

${ }^{10}$ Wawancara dengan Sdr. Iwan Kurniawan, Selaku Kepala Devisi Bagian Kredit Pemilikan Rumah, di Bank Tabungan Negara Cabang Palembang, pada Tanggal 11 Juni 2018. 
1) Perkara Nomor $148 / \mathrm{PNG} / 2005$

- Posisi Kasus

Daniel Indrajit Bin Marsan (Tergugat II) pada tanggal 23 Juli 1992 telah mendapatkan fasilitas kredit perumahan KPR-BTN No.33384.K2139 Q di Pondok Majapahit. Tergugat II telah menjual rumah tersebut pada Nyonya Erni Rosiani (Tergugat I). Tertuang dalam Perjanjian Jual Beli dan Pelimpahan dilegalisasi Notaris Sri Hadini Soejono No 1214/Leg/V/1996, juga telah dibuat kuasa notariil Nomor 13 dan Nomor 14 semua tertanggal 15 Mei 1996 untuk dan atas nama Tergugat II, untuk melakukan tindakan hukum misalnya mengangsur, melunasi dan mengambil sertipikat tanah, menjual dan mengalihkan kepada siapapun. Beralihnya obyek milik Tergugat II kepada Tergugat I, Tergugat I telah mengajukan permohonan alih debitur kepada Bank Tabungan Negara (Persero) dan telah dikeluarkan Surat Persetujuan Alih Debitur tertanggal 7 Juli 1996 Nomor 179/SMUt/Sps $\mathrm{Pu} / 1996$ perihal penegasan persetujuan alih debitur dengan persyaratan-persyaratan tertentu sebagaimana dimuat dalam surat tersebut. Persyaratan tersebut tidak pernah dipenuhi oleh Tergugat I, maka Perjanjian Kredit tetap berlaku atas nama Tergugat II. Pada tanggal 23 Januari 1997 oleh Tergugat I rumah dan tanah tersebut telah dijual kepada Penggugat di bawah tangan dan segala sesuatu surat berkaitan dengan obyek diserahkan kepada Penggugat.

Pengggugat secara rutin telah mengangsur melalui kantor pos setempat. Tergugat I dan Tergugat II kemudian tidak lagi berdomisili di tempatnya semula. Karena obyek masih atas nama Daniel Indrajit Penggugat tidak dapat mengambil sertipikat tanah tersebut di Bank karena hal tersebut hanya dapat dilakukan oleh debitur yang tercatatat di Bank.

Oleh Majelis Hakim atas perkara tersebut di atas diputus dengan mengabulkan untuk seluruhnya gugatan Penggugat. Tergugat I dan Tergugat II telah melakukan wanprestasi. Jual beli antara Tergugat I dengan Penggugat adalah sah dan Rumah sengketa di Pondok Majapahit Blok R 12 adalah sah milik Penggugat. Menghukum para Tergugat untuk tunduk dan patuh serta membayar biaya perkara.

Menurut penulis terhadap kasus tersebut di atas secara hukum dianggap belum pernah terjadi Pengalihan Hak atas rumah itu. Pengalihan hak atas rumah itu secara hukum baru terjadi apabila telah dilakukannya jual beli yang aktanya dibuat dengan akta PPAT dan kemudian ada balik nama sertipikat menjadi atas nama pembeli. Dengan demikian rumah itu masih milik debitur yang menjadi jaminan hutangnya kepada Bank.

Penjualan rumah KPR di bawah tangan oleh Debitur, tidak menghapuskan kewajiban Debitur untuk melunasi hutangnya kepada Bank. Perjanjian pengalihan kredit yang dibuat secara dibawah tangan hanya berlaku bagi para pihak yang membuatnya, dalam hal ini pihak bank selaku kreditur dan pihak nasabah peminjam selaku debitur. Oleh karena itu, pihak penerima pengalihan kredit tidak mendapat perlindungan hukum dari bank penyalur fasilitas kredit pemilikan rumah.

Pengalihan kredit dalam Kredit Pemilikan Rumah yang dilakukan secara dibawah tangan dapat diartikan bahwa pengalihan tersebut terjadi tanpa sepengetahuan pihak bank pemberi kredit. 
Dalam penulisan tesis ini dilakukan studi kasus terhadap pengalihan kredit KPR pada Bank BTN yang dilakukan tidak di hadapan pejabat yang berwenang. Adapun bentuk pengalihan tersebut adalah pengalihan terhadap tanah dan bangunan (rumah) yang menjadi objek jaminan dalam KPR BTN.

Pengalihan hak atas tanah dan bangunan melalui alih debitur KPR pada bank BTN terjadi karena jangka waktu kredit yang belum berakhir atau belum ada pelunasan dari debitur lama. Alih debitur terjadi setelah ada kesepakatan antara debitur lama selaku penjual dengan debitur baru selaku pembeli. Debitur lama yang bertindak selaku penjual akan mengalihkan objek yang akan menjadi haknya kepada pembeli dan pembeli selaku debitur baru bersedia untuk membayar sisa angsuran kepada bank yang terikat perjanjian KPR dengan Penjual yakni debitur lama setelah adanya persetujuan dari bank pemberi kredit.

Berdasarkan wawancara dengan divisi kepala bagian kredit pemilikan rumah, maka diketahui bahwa Bank BTN sama sekali tidak membenarkan seorang atau debitur melakukan pengalihan, penjualan atau apapun yang berkaitan dengan perjanjian kredit. Oleh karena perjanjian kredit hanya mengikat pihak bank dan debitur pertama saja. Dengan demikian, segala bentuk pengalihan, penjualan atau apapun yang dilakukan oleh debitur pertama terkait dengan perjanjian kredit tersebut yang mana dilakukan tanpa adanya izin tertulis terlebih dahulu dari Bank BTN adalah tindakan wanprestasi dan segala bentuk tindakan tersebut tidak akan mengikat pihak ketiga yaitu debitur baru.

Walaupun antara debitur pertama dan debitur baru telah melakukan perbuatan hukum berupa pengalihan debitur. Dalam menghadapi kenyataan Bank BTN hanya akan tetap menganggap debitur pertama yang melakukan perjanjian kredit dan perjanjian kredit tersebut tidak berlaku bagi pihak ketiga atau debitur baru.

Secara teoritis hal ini telah sesuai dengan ketentuan Pasal 1340 KUHPerdata yang menyatakan bahwa: "Perjanjian hanya berlaku bagi pihak-pihak yang membuatnya". Dengan demikian tidak mengikat pihak ketiga yaitu pihak yang menerima pengalihan kredit dari debitur pertama, karena perjanjian dalam KPR hanya mengikat pembeli (debitur) pertama dengan bank dan tidak mengikat pembeli secara dibawah tangan yang dilakukan tanpa sepengetahuan pihak bank.

1. Tindakan hukum kreditur (PT. Bank Tabungan Negara (BTN) cabang Palembang) untuk mencegah dan menyelesaikan peralihan kredit pemilikan rumah melalui perjanjian di bawah tangan antara debitur awal dengan pihak ketiga (debitur pengganti), dalam rangka melindungi kepentingan bank.

Langkah dan tindakan yang perlu diambil Bank untuk menyelamatkan kredit apabila mengetahui telah terjadi alih debitur di bawah tangan adalah sebagai berikut :

Bank dapat memperingatkan kepada debitur segera melunasi seluruh sisa hutang sebab meskipun rumah KPR telah dialihkan/dijual, secara hukum tidak menghilangkan kewajiban debitur, dengan kata lain debitur tetap bertanggung jawab untuk melunasi hutangnya. Harta kekayaan debitur yang lain tetap 
dapat disita oleh Bank untuk melunasi hutangnya. Tindakan atau perbuatan debitur dengan menjual rumah KPR, tanpa seijin Bank, Bank sebagai pemegang jaminan rumah KPR, dapat membatalkan penjualan rumah tersebut, jika Bank menghendaki.

Secara yuridis sebenarnya belum pernah terjadi jual beli, karena untuk sahnya jual beli (berikut rumah), harus ada akta jual beli dan balik nama sertifikat atau balik nama.

Dalam beberapa contoh kasus diatas telah terjadi alih debitur yang dilakukan di bawah tangan dan debitur lama kemudian tidak diketahui lagi domisilinya, maka menurut penulis langkah penyelesaiannya secara hukum adalah mengajukan gugatan perdata di Pengadilan Negeri setempat. Karena Pengadilanlah yang dapat memutuskan dengan pertimbangannya sendiri bahwa alih debitur yang dilakukan di bawah tangan dapat disahkan atau tidak. Sepanjang pihak bank tidak mempersoalkan atau membatalkan jual beli tersebut maka ada beberapa alternatif yang dapat ditempuh oleh Pihak Bank dan Pihak Pembeli untuk mengatasi kebuntuan hukum dari permasalahan tersebut.

Penyelesaiannya menurut penulis dapat ditempuh melalui 2 (dua) cara :

1. Debitur baru dapat terus membayar angsuran sampai lunas sesuai jangka waktu atau dapat melunasi sekaligus secara tunai dengan persetujuan bank dan akhirnya bank menyerahkan semua dokumen termasuk sertipikat kepada debitur baru tersebut tanpa harus dilakukan Balik nama.

2. Jika cara ke satu tidak tercapai dapat ditempuh cara kedua, yaitu dapat dilakukan alih debitur biasa tanpa memerlukan kehadiran debitur lama, dalam hal ini debitur lama dapat diwakili Bank berdasarkan surat kuasa menjual yang dibuat pada saat akad kredit. Bank dapat meminta Notaris/PPAT agar mau membantu cara ini dan sekaligus menjelaskan kepada Notaris/PPAT bahwa sebenarnya secara di bawah tangan rumah KPR tersebut telah dialihkan dari debitur lama kepada debitur baru dan telah menempati rumah itu. Namun karena pada kenyataanya debitur baru yang membayar angsuran dan debitur lama sudah tidak diketahui lagi alamatnya, maka permohonan debitur baru untuk alih debitur rumah tersebut sebaiknya dipertimbangkan untuk diterima.

Untuk alih debitur Bank dapat menggunakan Surat Kuasa Menjual sebagai dasar hukum Bank menjual/alih debitur kepada debitur baru. Namun untuk alih debitur ini perlu ada kesediaan PPAT/Notaris untuk membuat aktaaktanya. Yang menjadi problem kalau Notaris/PPAT tidak bersedia sehingga alih debitur tidak bisa terjadi. Untuk itu Kantor Bank harus mencari Notaris/PPAT yang bersedia atau meyakinkan Notaris/PPAT yang tidak bersedia agar bersedia membuat akta-akta.

Untuk mengamankan kepentingan Bank, debitur baru dapat diminta :

1. Untuk membuat surat pernyataan bahwa debitur baru telah membeli rumah KPR tersebut dan telah membayarnya kepada debitur lama dengan lunas, dan segala akibat yang timbul di kemudian hari menjadi tanggung jawab debitur baru sendiri serta membebaskan dan menanggung Bank dari semua tuntutan. 
2. Kwitansi bukti pembayaran dari debitur lama kepada debitur baru diminta dan disimpan Bank paling tidak fotocopy.

Apabila Notaris/PPAT bersedia membantu bank dalam membuat akta-akta alih debitur tanpa hadirnya debitur tetapi berdasarkan surat kuasa menjual dari debitur kepada Bank, yang dibuat debitur pada saat akad kredit maka akan sangat membantu menyelesaikan rumah KPR yang dijual dibawah tangan atau dalam keadaan kosong dan debitur tidak diketahui lagi.

Namun jika Notaris tidak bersedia membantu membuat akta alih debitur tanpa hadirnya debitur lama yang disebabkan rasa khawatir atau takut seperti yang kemukan pada jawaban di atas, upaya lain yang dapat ditempuh ialah dengan mengajukan gugatan melalui Pengadilan Negeri dimana rumah KPR terletak, kepada debitur yang tidak diketahui lagi itu. Tuntutan Bank dalam gugatan itu antara lain meminta agar Pengadilan Negeri mengijinkan Bank untuk menjual rumah KPR, baik secara tunai atau alih debitur tanpa hadirnya debitur lama.

Jika tergugat (debitur) telah dipanggil secara patut tidak pernah hadir, maka Pengadilan akan memberikan putusan Verstek (putusan tanpa hadirnya tergugat). Dalam waktu 14 hari sesudah putusan, tidak ada perlawanan dari debitur, putusan itu berkekuatan tetap, sehingga atas dasar putusan itu, Bank dapat menjual rumah tersebut baik tunai/alih debitur tanpa hadirnya debitur lama. Dengan Putusan Pengadilan Negeri itu, Notaris/PPAT tidak perlu ragu membuat akta alih debitur.

Menurut pendapat penulis berdasarkan Surat Kuasa Menjual dari debitur lama kepada Bank (yang sudah ada) yang dibuat dan ditandatangani pada saat atau bersamaan dengan perjanjian kredit (akad kredit), Bank dapat menjual langsung agunan kepada calon pembeli yang sudah setuju membeli. Bank tidak perlu ragu-ragu atau khawatir adanya risiko hukum akan kemungkinan debitur asli muncul dan menuntut Bank.

Munculnya debitur asli dan menuntut sangat kecil dan bahkan tidak mungkin karena faktanya debitur telah menjual (di bawah tangan) rumah agunan kepada orang lain itu. Kalau sendainya debitur muncul dan menuntut Bank maka Bank masih bisa membela diri dengan menjawab tuntutan itu secara hukum. Bahkan pembelaan Bank bisa dibenarkan Pengadilan.

Bank harus berusaha mencari Notaris/PPAT dan memberikan argumentasi atau penjelasan bahwa risiko membuat dokumen-dokumen kecil sekali bahkan tidak ada karena debitur sebenarnya sudah menjual kepada orang lain. Orang lain inilah yang mengajukan permohonan kepada Bank.

Penjelasan tersebut dengan tujuan agar Notaris/PPAT bersedia membuat dokumen yang diperlukan yaitu membuat akta jual beli dan balik nama sertipikat:

1. Untuk mengurangi risiko hukum bagi Bank maka pembeli di bawah tangan yang mengajukan permohonan menjual kepada Bank itu membuat pernyataan notariil atau di bawah tangan yang isinya bertanggung jawab penuh untuk mengganti kerugian jika debitur asli menuntut Bank dan membebaskan Bank dari segala tuntutan. Pernyataan itu digunakan sebagai bukti di kemudian hari bagi Bank jika seandainya debitur muncul dan menuntut kembali. 
2. Dengan adanya jual beli tersebut maka harga pembayaran digunakan untuk melunasi seluruh sisa hutang dan sisanya jika ada diberikan kepada orang yang mengajukan permohonan itu kepada Bank.

Hal yang sama juga dapat dilakukan oleh pihak bank untuk menyelesaikan kredit macet yang debiturnya tidak diketahui lagi dan rumah jaminan kosong (disebut Rukos), penyelesaian yang paling efektif dan cepat adalah dengan memanfaatkan Surat Kuasa Menjual (SKM) dari Debitur kepada Bank yang ditandatangani bersamaan pada saat akad kredit. Dengan SKM tersebut Bank menjual kepada yang berminat dengan pambayaran tunai atau dengan alih debitur Bank atas nama debitur yang raib mengalihkan kepada pembeli dengan pembayaran tunai atau dengan meneruskan angsuran. Penjualan tunai atas agunan atau dengan cara alih debitur harus dengan bantuan Notaris/PPAT yang membuat dokumen tersebut. Namun apabila Notaris/PPAT tidak bersedia membuat dokumen alih debitur atau akta jual beli dengan pembayaran tunai dengan alasan debitur tidak ada.

Pengadilan Negeri nantinya akan memberikan putusan tanpa hadirnya Tergugat (debitur yang raib/Verstek) apabila debitur dipanggil tidak pernah hadir. Putusan Pengadilan Negeri akan menjadi putusan yang tetap apabila dalam waktu 14 hari sejak diucapkan tidak ada perlawanan (verzet) dari debitur yang bersangkutan, sehingga memberikan hak yang penuh kepada Bank untuk mengalihkan tanpa hadirnya debitur, dan putusan Pengadilan Negeri itulah yang memberikan perlindungan kepada Notaris/PPAT yang bersangkutan.
1. Konsep peralihan kredit pemilikan rumah antara debitur awal dengan pihak ketiga (debitur pengganti), yang seharusnya di masa yang akan datang.

Banyaknya permasalahan yang muncul dalam proses alih debitur (over kredit) Perumahan, Penulis menemukan beberapa cara agar proses peralihan kredit tidak bertentangan dengan hukum, beberapa cara tersebut sebagai berikut :

\section{Proses Resmi Melalui Bank}

Melakukan over kredit melalui bank adalah cara paling aman dan kuat berdasarkan hukum. Dalam proses over kredit ini, anda dan penjual rumah harus bersama-sama menghadap bank untuk proses memindahkan nama pemilik rumah lama pada nama anda sebagai pemilik baru. Pihak Bank akan meneliti dan menganalisa kemampuan finansial Anda melalui berkasberkas keterangan penghasilan, rekening tabungan, listrik, air, dan telepon. Bila memenuhi standart kelayakan kredit rumah KPR, maka permohonan anda untuk mengalihkan kredit akan segera disetujui.

Pihak bank akan mengenakan biaya over kredit, notaris, asuransi dan lain-lain pada anda sebagai pemilik rumah baru. Pihak bank akan membuat surat perjanjian Kredit baru atas nama pemilik rumah baru beserta akta jual beli dan pengikatan jaminan. Secara resmi pihak bank mengganti nama anda sebagai debitur atau pembayar kredit rumah KPR dari debitur lama.

Anda sebagai debitur berhak bertanya pada pihak bank tentang besaran angsuran dan bunganya. Seharusnya besaran angsuran rumah tetap seperti angsuran lama, hanya perhitungan suku bunga yang berubah bila menggunakan floating rate. 
Lima langkah aman cara over kredit rumah melalui bank yang wajib anda ikuti adalah:

1) Tahap pertama adalah, Pihak penjual dan anda sebagai pihak pembeli harus bersama-sama mendatangi bank yang memberikan kredit kepemilikan rumah.

2) Tahap kedua periksa kelengkapan pihak penjual rumah. Dalam hal ini adalah sertifikat rumah yang dijual. Tentunya sertifikat rumah ini berada dalam anggunan bank. Selain itu pihak penjual harus melengkapinya dengan data-data pribadi yang diminta oleh pihak bank. Oleh sebab itu Anda dan pihak penjual harus menghadap bersama ke bank untuk proses over kredit rumah.

3) Tahap ketiga adalah giliran Anda sebagai pihak pembeli atau pihak yang hendak mengambil alih angsuran kredit rumah KPR. Kelengkapan dokumen tersebut adalah KTP, KK, slip gaji, surat keterangan kerja, dan fotokopi mutasi keuangan selama 3 bulan terakhir. Dokumen ini akan menjadi pertimbangan dari pihak bank untuk melanjutkan proses diterima atau tidaknya over kredit tersebut kepada Anda.

4) Tahap keempat adalah pihak penjual rumah KPR diminta mengajukan permohonan ambil alih kredit kepada debitur baru yaitu Anda. Pihak bank akan mengganti nama debitur lama menjadi nama Anda sebagai debitur baru.

5) Tahap kelima adalah persetujuan dari pihak bank. Setelah pihak bank menyetujuinya, maka Anda sebagai pihak debitur baru diminta menandatangani kredit baru atas nama
Anda beserta akta jual beli dan pengikat jaminan dari pihak notaris.

Cara over kredit melalui pihak bank adalah cara paling aman. Meskipun harus mengeluarkan biaya cukup banyak untuk administrasi over kredit sekaligus biaya notaris, namun langkah ini sangat kuat di mata hukum. Anda pun sudah bisa menjual rumah ini kepada pihak lain.

\section{Proses Resmi Melalui Notaris.}

Proses resmi melalui notaris ini dapat dilakukan dengan cara yaitu pembeli dan penjual mendatangi pihak notaris untuk dibuatkan akta subrogasi (perjanjian utang piutang subrogasi). ${ }^{11}$ Adapun tujuan utama dari perjanjian subrogasi ini adalah untuk menggantikan kedudukan debitur lama dari hutang-hutangnya.

Proses ini haruslah diketahui dan melibatkan pihak kreditur dalam hal ini yaitu Bank Tabungan Negara (BTN) Cabang Palembang karena dalam pembuatan akta subrogasi, Notaris/PPAT haruslah melihat Sertifikat asli yang masih dijaminkan di bank. Setelah Notaris/PPAT melihat sertifikat asli yang dibawa oleh pihak bank, barulah dapat dibuatkan akta subrogasi (perjanjian utang piutang subrogasi).

Tiga langkah aman over kredit rumah melalui notaris:

1) Pihak Penjual, lalu anda sebagai pembeli rumah yang akan dialihkan kreditnya dan pihak bank mendatangi notaris bersama. Biaya notaris biasanya ditanggung kedua belah pihak (debitur). Namun untuk lebih amannya, pilih notaris yang telah anda percaya dalam

\footnotetext{
${ }^{11}$ Obbi Afri Gultom, Perjanjian Utang Piutang Subrogasi, dikutip dari http://www.gultomlawconsultants.com/contohperjanjian-utang-piutang-subrogasi.html, diakses pada tanggal 05 Juli 2018.
} 
2) proses pengalihan kredit rumah tersebut dengan biaya anda sebagai pembeli.

3) Siapkan kelengkapan dokumen anda dan juga penjual rumah. Dokumen tersebut meliputi KTP, KK, dan dokumen yang diminta notaris. Pihak penjual akan diminta membuat surat pernyataan bahwa rumah KPR tersebut dialihkan kepada anda sebagai pemilik rumah baru.

4) Notaris akan membuat akta subrogasi yang akan ditandatangani oleh para pihak.

Proses melalui notaris ini cukup murah biayanya dibandingkan melalui proses perubahan nama debitur langsung melalui bank. Anda hanya perlu mengeluarkan biaya jasa notaris saja.

\section{KESIMPULAN DAN SARAN}

Perjanjian pengalihan kredit (over credit) secara di bawah tangan hanya berlaku bagi para pihak yang membuatnya saja dalam hal ini debitur yang mengalihkan kredit dan debitur yang menerima pengalihan kredit, pihak bank tetap hanya mengakui debitur pertama yang mengajukan proses KPR di bank yang sah sehingga debitur penerima pengalihan kredit tersebut tidak memperoleh kepastian dan perlindungan hukum.

Penjualan rumah KPR di bawah tangan oleh debitur yang belum melunasi hutangnya tidak menghapuskan kewajiban debitur untuk melunasi hutangnya kepada Bank. Sehingga Bank dapat menuntut debitur untuk memberikan ganti kerugian atas jual beli rumah KPR oleh debitur lama yang dilakukan di bawah tangan dan segera melunasi seluruh sisa hutangnya. Serta Bank dapat melakukan gugatan berupa menjual objek Kredit yang dijadikan sebagai jaminan KPR.

Penulis menemukan beberapa cara agar proses peralihan kredit tidak bertentangan dengan hukum, beberapa cara tersebut sebagai berikut:

1). Melalui proses resmi bank,

2). Melalui proses resmi notaris.

Saran, untuk
diharapkan pihak bank, selalu memperhatikan dan menerapkan prinsip kehati-hatian (prudential banking) dan melakukan analisis kredit secara cermat, teliti dan mendalam dari berbagai aspek berdasarkan prinsip-prinsip yang berlaku secara universal dalam dunia perbankan, untuk menghindari atau mengantisipasi munculnya pengalihan kredit secara tidak resmi, begitupula debitur penerima over credit untuk mencari informasi yang seluasluasnya kepada bank mengenai kondisi kredit debitur lama dan menghindari pengalihan kredit diluar dari ketentuan bank guna menghindari terjadinya berbagai masalah yang berkaitan dengan objek KPR secara over credit.

Untuk menghindari timbulnya permasalahan dikemudian hari maka masyarakat yang ingin melakukan alih debitur atas KPR BTN dapat melakukannya setelah mendapatkan persetujuan dari pihak bank selaku kreditur. Untuk kepentingan tersebut baik debitur lama maupun calon pembeli harus dengan itikad baik melaksanakannya dengan terlebih dahulu mencari informasi yang jelas di PT Bank Tabungan Negara (Persero) setempat yang memberikan fasilitas kredit, agar tidak terjadi kesalahan dalam proses alih debitur akibat ketidakpaham para pihak. 
Terhadap perjanjian kredit, lebih baik dilakukan dengan akta notaris, karena kekuatan pembuktian akta notaris adalah pembuktian yang sempurna, serta dengan di buatkan dalam bentuk akta notaris maka perjanjian kredit tersebut lebih memberikan jaminan terhadap para pihak yang membuatnya.

\section{DAFTAR PUSTAKA}

Buku

Soejono Soekanto, 2010, Penelitian Hukum

Normatif Suatu Tinjauan Singkat,

Jakarta : PT. Raja Grafindo Persada.

Suharnoko, 2005, Doktrin Subrogatie,

Novasi, dan Cessie, Jakarta:

Kencana.

Thomas Suyatno, 2007, Dasar-Dasar Perkreditan, Jakarta: PT. Gramedia Pustaka Utama.

Zainal Asikin, 1995, Pokok-Pokok Hukum

Perbankan di Indonesia, Jakarta: PT. Raja Grafindo Persada.

Jurnal

Erma Deviana Putriyanti, "Legal Status of Credit Bank Guarantee in Indonesia's Legal Guarantee", Jurnal Hukum Sriwijaya Law Review, Volume 1, Issue 2, July 2017, hlm. 3.

Rakhmad Susatyo, "Aspek Hukum Kredit Bermasalah Di PT. Bank International Indonesia Cabang Surabaya", Jurnal Hukum Vol. 7, No. 13, hlm. 14. 